\title{
LA IDEA DE MÉRITO EN LA ANTIGÜEDAD GRIEGA
}

\section{THE IDEA OF MERIT IN ANCIENT GREECE}

\author{
Jesús García Cívico ${ }^{1}$ \\ Universitat Jaume I
}

Recibido: 6/ 6/ 16

Aceptado: 29/ 9/ 16

Resumen: Este trabajo aborda la idea de mérito en la antigüedad griega. Se analizan las interpretaciones históricas de la idea de mérito personal: areté y acción heroica en los poemas de Homero, el esfuerzo y el sacrificio personal ( $p o-$ nos) en Hesíodo, los argumentos a favor de la eugeneia y los méritos de las clases privilegiadas frente a los pobres, aristocracia y gobierno del filósofo rey en Platón, así como la virtud en Aristóteles. Finalmente se presenta la época de la democracia de Pericles como un intento original de conciliar mérito e igualdad.

Palabras clave: mérito, igualdad, antiguedad griega, Homero, Hesíodo, Platón.

\begin{abstract}
This paper addresses the idea of merit in Ancient Greece. Historical interpretations of desert: heroic actions and arete in Homer's poems, personal effort and sacrifice (ponos) in Hesiod's works, the reasons in favor of the eugeneia and the merit of the privileged classes against the poors, aristocracy and the Plato's philosopher king rule as well as the virtue in Aristotle. Finally, the age of Periclean democracy is presented as an original attempt to reconcile merit and equality.
\end{abstract}

Key words: merit, equality, Ancient Greece, Homer, Hesiod, Plato.

1. (civico@dpu.uji.es) Profesor de Filosofía del derecho. Área filosofía del derecho, Departamento de derecho público, Facultad de ciencias jurídicas y económicas, Universitat Jaume I (Castellón de la Plana). Centro de Investigación de la Efectividad de los Derechos Humanos. 
Es un hecho fundamental de la historia de la cultura que toda alta cultura surge de la diferenciación de las clases sociales, la cual se origina, a su vez, en la diferencia de valor espiritual y corporal de los individuos.

Werner Jaeger, Paideia

Según el crédito que cada cual consiga en una actividad, no se le prefiere por la riqueza más que por sus méritos.

Tucídides. Oración fúnebre a los caídos en el primer año de la Guerra del Peloponeso

\section{Introducción}

La idea de mérito constituye un concepto central en las reflexiones contemporáneas acerca de la justicia. En el ámbito anglosajón se asume explícitamente que todo debate sobre la justicia distributiva pasa por el equilibrio entre dos valores en tensión: la igualdad material (o la solidaridad) y el principio del mérito personal (desert $)^{2}$.

El mérito personal entendido como acción que hace a una persona merecedora de estatus y posiciones o acreedora de un determinado cargo o beneficio lleva implícita la idea de desigualdad legítima. Efectivamente, muchas de las desigualdades materiales (salariales, o en general, retributivas) que hoy se presentan como legítimas están asociadas a exigencias morales o estratégicas (premios, beneficios, procesos de selección y promoción laboral, acceso a cargos públicos, etc.) relativas a la valoración de méritos personales, entendiendo por estos la capacidad (o capacitación) la inteligencia, el esfuerzo, la aportación o desempeño individual en una empresa privada o en el acceso y promoción en la función pública.

Todo esto remite, como es sabido, a aquel conjunto de ideas que se opuso a los privilegios estamentales de tipo adscriptivo-natalicio que habitualmente situamos en la modernidad. Locke fue de los primeros en asociar el ingenio y esfuerzo individual en la base de la justificación de la

2. Entre otras, Miller, D.: The Principles of Social Justice, Cambridge, MA: Harvard University Press, 2000: p. 131- 155. FEINBERG, J.: «Justice and Personal Desert» en Nomos VI: Justice, 1963: pp. 69-97. KLEINIG J.: «The Concept of Desert» en American Philosophical Quarterly, 1971, pp. 71-78. LAMONT, J.: «The Concept of Desert in Distributive Justice» en Philosophical Quarterly 44, 1994, pp. 45-64. SHER, G.: «Effort, Ability, and Personal Desert» en Philosophy and Public Affairs 8, 1987, pp. 361-76. YOUNG, R.: «Egalitarianism and the Modest Significance of Desert», en Ethics 102, 1992.

Thémata. Revista de Filosofía $\mathrm{N}^{\circ} 55$ (2017) pp.: 219-248. 
desigualdad material. La formulación se encuentra en el Segundo ensayo sobre el gobierno civil: "Cada hombre es propietario de su propia persona [...] el trabajo de su cuerpo y la labor de sus manos son también suyos». ${ }^{3}$ Más tarde, Adam Smith, asume el desarrollo de ese esfuerzo individual como clave de un proyecto de filosofía político-económica: «El esfuerzo natural de cada individuo por mejorar su propia condición [...] es un principio tan poderoso por sí mismo capaz no solo de conducir la sociedad hacia la riqueza y la prosperidad, sino de superar cien obstáculos impertinentes con que la locura de las leyes humanas a menudo dificulta sus operaciones». ${ }^{4}$

La búsqueda del propio interés fue celebrada como pasión benigna (más allá de su corroboración empírica) prácticamente en todas partes, así lo recoge el atractivo ensayo del sociólogo Albert O. Hirschman, Las pasiones y los intereses. Weber subrayó, como es sabido, que fue precisamente el espíritu del ascetismo protestante lo que engendró uno de los elementos constitutivos del moderno espíritu capitalista, y no sólo de éste, sino de la misma civilización moderna: la racionalización de la conducta sobre la base de la idea profesional. Los elementos del espíritu del capitalismo coincidieron con el contenido de la ascesis profesional puritana y con la desigual productividad del trabajador. ${ }^{5}$ En lo que toca al ámbito público, la idea quedó perfectamente reflejada en el artículo $6^{\circ}$ de la Declaración de Derechos del Hombre y del Ciudadano de 1789: «La ley es la expresión de la voluntad general. [...] Todos los ciudadanos al ser iguales ante ella, son igualmente admisibles a todas las dignidades, puestos y empleos públicos, según su capacidad y sin otra distinción que sus virtudes y sus talentos».

Entonces, ¿es posible hablar de merito en la antigüedad griega?

\section{El mérito no es una idea liberal ${ }^{6}$}

Cabe entender el recelo que provoca enlazar la noción de mérito con la idea de merecimiento sin reconducirla al principio de capacidad individual. ${ }^{7}$ Sin embargo, debemos retener una primera idea: el mérito es un

3. LOCKE, J.: Dos ensayos sobre el gobierno civil, Madrid: Austral, 1997, p. 223.

4. SMITH, A.: Investigación sobre la naturaleza y causas de la riqueza de las naciones, Madrid: Alianza, p. 460.

5. WEBER M.: Ética protestante y el espíritu del capitalismo, Barcelona: Península: p. 257.

6. Para Jean Pierre Dupuy, «todas las concepciones de la justicia son por regla general suavemente meritocráticas». DUPUY, J. P.: El sacrificio y la envidia. El liberalismo frente a la justicia social, Barcelona: Gedisa, 1998, p. 195.

7. HELLER, A.: Más allá de la justicia, Barcelona: Crítica, 1990

Thémata. Revista de Filosofía $\mathrm{N}^{\circ} 55$ (2017) pp.: 219-248. 
concepto amplio y contingente. Chaïm Perelman tomaba el mérito como noción "cuyo uso sólo se concibe en función de su misma confusión» ${ }^{8}$. Amartya Sen comenzaba un breve análisis de la relación entre mérito y justicia llamando la atención sobre la falta de claridad de los términos relacionados con el mérito. Se trata de una idea cultural relacionada con lo que cada sociedad considera valioso o digno de recompensa ${ }^{9}$. De acuerdo con el teórico del derecho y filósofo político Norberto Bobbio, no hay teoría de justicia que no analice y discuta, implícita o explícitamente, alguno de los criterios de la justicia que por lo común se presentan como especificaciones de la máxima general y vacía: "A cada uno lo suyo» ${ }^{10}$. Dar a cada uno lo suyo remite de forma circular al sentido de lo que cada persona merece, aunque no sean, propiamente, expresiones idénticas. Existe de hecho una antigua tradición iniciada en la poesía homérica, en la paideia griega, y en las primeras reflexiones sobre la justicia de Platón, Aristóteles, que atraviesa la obra de Locke o Stuart Mill, retomada más tarde por Michael Walzer o Wojciech Sadurski, según la cual la idea de mérito (desert) o merecimiento (merit) y la acción o el hecho de merecer (deserve, verdienen) guardan una estrecha relación con la justicia, de acuerdo con la máxima justicia es dar a cada cual lo que se merece. ${ }^{11}$ Alrededor de la noción de mérito se siguen articulando discursos que plantean una relación causal entre la recompensa (premio o castigo) la noción amplia de merecimiento o mérito (como su concreción) y la noción de justicia como instancia crítica sobre la que es posible evaluar todo ello. También se ha denunciado, y creemos que con razón, que las enormes desigualdades materiales y de condiciones de vida que caracterizan nuestra época encuentran, a menudo, su justificación última en expresiones del tipo «la gente tiene lo que se merece».

En general, la idea de mérito aparece estructurada por dos parámetros formales: la idea de lo justo desigual y la lucha o contexto de competencia (naturaleza agonal del modelo social). Lo «justo desigual» resulta de una aplicación de la idea de justicia por la cual es correcto tratar igual lo igual pero de forma desigual lo que es desigual. Es decir, la idea remite constantemente a los criterios de justicia y a la vez a una amplia idea de merecimiento. Es por ello, por empezar a centrarnos en el objeto específico de este trabajo, que en el pasado que nos interesa, el mérito for-

8. PERELMAN, CH., OLBRECHTS TYTECA, L.: Tratado de la argumentación, Madrid: Gredos, 1998, p. 215.

9. SEN, A.: «Merit and Justice» en ARROW, K., BOWLES, S., DURLAUF, S.,: Meritocracy and Economic Inequality, Princeton University Press, 2001, p. 5.

10. BOBBIO, N.: Igualdad y libertad, Barcelona: Paidós, 1993, p. 63.

11. POJMAN, L. P., McLEOD O.: What Do We Deserve? A Reader on Justice and Desert, New York: Oxford University Press, 1999, pp. 10- 56.

Thémata. Revista de Filosofía $\mathrm{N}^{\circ} 55$ (2017) pp.: 219-248. 
ma parte de la dikaiosyne, esto es, no de la justicia como norma específica, sino del «sentido de lo justo» propio de ese amplísimo tiempo que llamamos "antigüedad griega» en el que las convenciones legales descansan tanto sobre la díke, esto es, justicia como norma, como sobre el sentido de lo justo.

Las acciones son valoradas o castigadas bajo ese sentido general de lo justo. Es preciso recordar que los griegos, con un consenso suficiente, consideraron la justicia en un sentido más general que el moderno: algo se tiene como justo en la medida en que su existencia no interfiere en el orden al cual pertenece. La acción que Hannah Arendt estudió en La condición humana como lo "genuinamente humano» ${ }^{12}$ mantiene una estrecha relación con el discurso que, siguiendo a esta autora, constituye una forma de acción: la ocasión de apropiarse uno de lo que es suyo. Este «apropiarse el sujeto de lo que es suyo» permite acercarnos al mérito como título justificativo de la adquisición desigual. Es así que Jean Paul Vernant recuerda al hilo de las transformaciones psicológicas del hombre antiguo que el nacimiento del concepto de mérito es inescindible del nacimiento del concepto de sujeto ${ }^{13}$.

Efectivamente, jaunque Vernant se refiere al moderno concepto de mérito y por eso dice que su «condición de posibilidad es el reconocimiento de virtudes individuales que si bien pueden ser suscitadas por un dios, no dependen del linaje ni -al menos en forma declarada- de la riqueza económica»! Pero el contenido y alcance del mérito en la antigüedad no es, no puede ser, el mismo que en la modernidad. En realidad, como el mismo Vernant ha explicado antes, sólo puede decirse, que junto al sujeto nace el ideal de la excelencia (areté), que presenta una acepción según el cual cada persona deberá ser capaz de alcanzar el dominio de sí misma sobre la base de sus propias destrezas y capacidades.

El campo al que nos asomamos es más rico y variado que la concreción epocal del mérito en la génesis de la modernidad. El mérito no es un concepto de filiación liberal, sino que bajo distintas expresiones y contenidos acompaña la historia de la política. También acompaña la historia de las ideas en Grecia en un variado campo léxico, las más de las veces en el ámbito semántico de la "axía», la "areté» y otros términos a los que enseguida eludiremos. Heródoto señala que en la tiranía «el tirano envidia a los hombres de mérito» ${ }^{14}$, que «en la oligarquía, muchos quieren imponer su mérito.»" Leemos en Leyes de Platón que "[Zeus]... a quién más méritos posee le concede mayores distinciones y honores, y lo mismo en lo que

12. ARENDT, H.: La condición humana, Barcelona: Paidós, 1993.

13. VERNANT, J. P.: «El individuo en la ciudad», en VVAA: Sobre el individuo, Barcelona: Paidós, 1990, p.36.

14. HERÓDOTO: III, 80.

15. HERÓDOTO: III, 82.

Thémata. Revista de Filosofía N55 (2017) pp.: 219-248. 
corresponde por virtud y educación. Y yo creo que para nosotros la política es precisamente esto, la justicia en sí misma ${ }^{16}$. En Aristóteles, el ideal de justicia como dar a cada uno según su mérito aparece en el libro VIII de Ética a Nicómaco frente al ideal de amistad que es «devolver igual cantidad de afecto y servicio». Así, la justicia puede ser distributiva (proporción geométrica) o reguladora (proporción aritmética); la amistad puede ser igualdad o proporción (en caso de superioridad de una de las partes) ${ }^{17}$. Dar a cada uno según su mérito significa también asignar derechos sobre la base de distintos rasgos y acciones. Así, cuando Aristóteles analice las formas de regímenes políticos y establezca una graduación en términos de buenos y malos, y ordene: realeza, aristocracia, timocracia, democracia, oligarquía y tiranía, dirá que en la oligarquía "se distribuyen los bienes de la ciudad en contra del mérito» ${ }^{18}$. Para Aristóteles democracia significa "predominio del número sobre el mérito» mientras que en Tucídides encontraremos, a modo de alabanza, la democracia como política que no tiene en cuenta «la oscura pobreza» sino que prefiere al ciudadano por su mérito (axiosis). ${ }^{19}$

\section{Algunos estudios precedentes}

Exceptuando las apelaciones historiográficas de Allison o Adkins ${ }^{20}$, el recorrido por la historia de las ideas de Pojman y McLeod o las recientes observaciones de Domenico Musti a la meritocracia al hilo de su teoría de la demokratía, no existe, hasta donde alcanzamos, muchas más bibliografía que aborde directamente la forma que la idea de mérito tomó en la antigüedad. La referencia a una "Atenas burguesa" ocupa un lugar central en los estudios clásicos de Vidal-Naquet, o de Finley y es en el seno de lo que estos autores llaman «burguesía ateniense», donde cabe encontrar referencias, ya indirectas, a la idea de mérito en sentido moderno. La obra magna de Ste Croix La lucha de clases en el mundo griego antiguo ${ }^{21}$ supone una crítica materialista a la explotación en la Grecia antigua y por lo tanto contiene referencias a los argumentos de las clases dominantes, los más de

16. PLATÓN: Leyes, 757 a y ss.

17. ARISTÓTELES: Ética a Nicómaco, 1158b 15-30.

18. ARISTÓTELES: Ética a Nicómaco, 1160b 10-15.

19. TUCÍDIDES: II, 37.

20. ADKINS, A. W. H.: Merit and Responsability: A Study in Greek Ethics, University of Chicago, 1960. ALLISON, J. W.: "Axíosis, the New Arete: A Periclean Metaphor for Friendship», The Classical Quaterly, Oxford, Vol. 51, 2001: pp. 53-64.

21. STE CROIX, G.: La lucha de clases en el mundo griego antiguo, Barcelona: Crítica, 1988.

Thémata. Revista de Filosofía $\mathrm{N}^{\circ} 55$ (2017) pp.: 219-248. 
las cuales apelan a una idea de mérito. ${ }^{22}$

Las alusiones a estos conceptos aparecen muy rara vez de forma explícita en los estudios clásicos sobre la antigüedad política griega. En la época en la que la idea de mérito individual cobró una importancia capital, esto es, en la génesis del liberalismo económico, los ensayos ilustrados sobre ese punto de la historia antigua miraban más a Roma que a Grecia ${ }^{23}$. La recepción ilustrada del precedente democrático griego, a menudo tras este filtro latino, sirvió a Montesquieu y Rousseau ${ }^{24}$ para retomar distinciones clásicas entre diferentes sistemas de gobierno y arremeter, siguiendo la tradición democrática antigua, contra el despotismo y los privilegios de tipo aristocrático y los argumentos de una desigualdad natural que los legitima. Asimismo y siguiendo los primeros escritos de Nietzsche, la interpretación romántica tardía alemana de la antigüedad griega subrayó el elemento "burgués ilustrado» ${ }^{25}$ en Homero, que luego Adorno y Horkheimer relacionarían con el mito en Dialéctica de la Ilustración. En el análisis que los autores de la Escuela de Frankfurt hicieron del origen y naturaleza de la razón instrumental, defendían que «las líneas de la razón, la liberalidad y el espíritu burgués» se extendían más allá de la concepción histórica que data el origen del concepto burgués sólo a partir del feudalismo medieval. ${ }^{26}$

A pesar de los esfuerzos de autores como Havelock o Strauss, la búsqueda de una presencia «liberal» en la antigüedad griega, resulta, según creemos, únicamente comprensible, y en nuestra opinión con muchas cautelas, desde una visión demasiado extensa y flexible del término «liberalismo» como teoría que da mayor importancia a la libertad que a la autoridad. ${ }^{27}$ En todo caso, los autores que creen ver el aspecto «liberal» en la antigüedad griega o en determinados filósofos antiguos, han partido de esa defensa de la libertad personal frente a la autoridad, y concretamente,

22. AUSTIN, M., VIDAL-NAQUET, P.: Economía y sociedad en la Grecia antigua, Barcelona: Paidós, 1986. VIDAL-NAQUET, P.: La democracia griega: ensayos de historiografía antigua y moderna, Madrid: Akal, 1992. PLÁCIDO, D.: La sociedad ateniense: la evolución social en Atenas durante la guerra del Peloponeso, Barcelona: Crítica, 1997.

23. FINLEY, M. I.: Esclavitud antigua e ideología moderna, Barcelona: Crítica, 1982, pp. 22. 24. «Aquel que cantaba o danzaba mejor; el más bello, más fuerte, más diestro, más elocuente se convirtió en el más considerado, y éste fue el primer paso hacia la desigualdad [...] de estas primeras preferencias nacieron [...] el mérito y los talentos». ROUSSEAU, J. J.: Sobre el origen de la desigualdad, Madrid: Alianza, 1994, p. 262.

25. Sobre las expresiones liberales en el modelo democrático de la época clásica, vid. por todos, HAVELOCK, E. A.: The Liberal Temper in Greek Politics, New Haven: 1957.

26. Este es el punto de partida del primer excurso en HORKHEIMER, M., ADORNO, T. W.: Dialéctica de la Ilustración, Barcelona: Península, 1998.

27.Havelock sostiene «[...] che un liberalismo puro essieve nel pensamiento pre-platonico» en STRAUSS, L.: Liberalismo antico e Moderno, Milano: Giueffrè editore, 1968, p. 27.

Thémata. Revista de Filosofía $\mathrm{N}^{\circ} 55$ (2017) pp.: 219-248. 
en la teoría democrática, frente a visiones holistas de la polis o la sociedad jerárquica en su conjunto.

En la bibliografía contemporánea sobre política y sociedad en la antigüedad griega las referencias al mérito, sin ser su articulación una idea central en ellas, aparecen de nuevo en líneas de investigación centradas en la historia socio-económica ${ }^{28}$, en la comparación entre democracia antigua y moderna ${ }^{29}$, otra vez en la supuesta «impronta liberal» de la democracia ateniense. En relación con este último sentido, recientes estudios resaltan frente a la tradicional concepción holista de la antigüedad, un rasgo particular del pensamiento liberal: la corriente «individualista» ${ }^{30}$ paradigmáticamente en la concepción democrática de la época de Pericles ${ }^{31}$.

Todo esto apoyaría, explícita o implícitamente ${ }^{32}$, la posibilidad cautelosa de hablar de un modelo meritocrático ${ }^{33}$ en el componte democrático de la antigüedad griega.

\section{Claves y campos semánticos: axiosis, axioma y areté}

El carácter ambiguo de la noción de mérito no es algo exclusivo de nuestra época, precisamente la riqueza del léxico griego aumenta la dificultad de encontrar un único equivalente. Además ésta se acentúa merced a la existencia de todo un conjunto de teorías, que en la antigüedad, y alrededor de la idea de «desigualdad natural», tratan de justificar el poder de

28. También e influido por los acontecimientos del siglo XX, el clásico de Popper, The Open Society and its enemies: en clave antitotalitaria, y según su interpretación, «antiplatónica»

29. Entre otros, vid., BOBBIO, N.: El futuro de la democracia, México: FCE, 1986.

30. Según Salvador Giner, puede entenderse el individualismo como una de las corrientes predominantes en la filosofía occidental. Arranca en la antigüedad griega, está presente en la visión de Pericles, [...] la actitud renacentista y se caracteriza por la centralidad y autonomía del individuo en su manera de concebir la dinámica y la estructura de la sociedad. GINER, S.: Historia del pensamiento social, Barcelona: Ariel, 1994, p. 293 y ss.

31. Para Musti «[a la ciudad antigua] no le falta ni una dosis de individualismo, distinto en cada época pero siempre presente al menos en el plano teórico, en la democracia períclea, ni el pluralismo MUSTI, D.: Demokratía, Orígenes de una idea, cit., p. 342.

32. Dumont, contrapone individualismo y holismo. DUMONT, L., Homo aequalis. Génesis y apogeo de la ideología económica, Madrid, Taurus, 1999, p. 14

33.La expresión "meritocracia», parece un neologismo de Michael Young en la sátira The rise of Meritocracy, obviamente desconocido tanto en Roma como en Grecia, de cuyas lenguas tomaba respectivamente los componentes de la palabra: meritum / kratos. El superlativo de

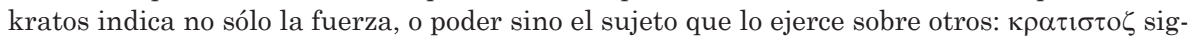
nifica: más fuerte, más poderoso, mejor, más hábil pero también aristócrata, noble.

Thémata. Revista de Filosofía $\mathrm{N}^{\circ} 55$ (2017) pp.: 219-248. 
un grupo sobre otro recurriendo a la mejor valía. Las expresiones básicas parecen ser: axiosis, axioma ${ }^{34}$ y areté.

\subsection{Areté y aristeúein}

La noción de mérito es contingente y relativa a lo que en cada momento una sociedad considera valioso o digno de premio, por ello, los estudiosos de este periodo coinciden en señalar la conexión entre areté (virtud, excelencia) y valores dominantes. Esto es, conectado con el trasfondo agonal en que se recompensa el mérito hallamos el contenido contingente que éste comienza adoptando. En Qué es la política, Arendt agrega que en el concepto de aristeúein se ve la aspiración del ciudadano a mostrar lo mejor en cada ocasión: "Esta competencia todavía tenía su modelo en la lucha escribe-, que es completamente independiente de la victoria o la derrota y que dio a Héctor y a Aquiles la oportunidad de mostrarse tal como eran, de manifestarse realmente, o sea, de ser plenamente reales». ${ }^{35}$ En el desarrollo histórico del concepto de areté ésta es eminentemente agonal y aristocrática: "Señorío y areté se hallaban indisolublemente unidos». ${ }^{36}$ Aquí la raíz de la palabra areté remite ya al superlativo de distinguido y selecto, el cual en plural era constantemente usado para designar a la nobleza. Asimismo, parece lícito vincular el ideal de la areté con la valoración social de las aptitudes, o si se quiere con el ideal meritocrático (aristocrático en su germen) que incluye hechos independientes de la voluntad y control del individuo, así el nacimiento bueno o noble (eugeneia) es considerado sinónimo de aptitud.

En el principio, la acepción de la areté más próxima a la idea moderna de mérito tiene que ver con los hechos heroicos pues, como sabemos, desde Homero los griegos consideraron la destreza y la fuerza sobresalientes como el supuesto evidente de toda posición dominante. El poeta exalta la verdadera areté sobre cualesquiera otros bienes que pudieran otorgar un valor y una consideración al hombre: ${ }^{37}$ "No quisiera mantener la memoria de un hombre ni hablar de él por la virtud de sus pies ni por la destreza en la lucha, aun cuando tuviera la grandeza y la fuerza de los cíclopes y venciera en velocidad al tracio Boreas». Para Jaeger, estos son «ejemplos eminentes de la areté agonal, que los caballeros desde tiempos de Homero,

34. Para la distinción de estas expresiones en Tucídides, además de las obras ya reseñadas, ALLISON, J. W.: Word and Concept in Thucydides, American Classical Studies, 41, 1997.

35. ARENDT, H.:¿Qué es la política?, Barcelona: Paidós, 1997, p. 110.

36. JAEGER, W.: Paideía, Los ideales de la cultura griega, México: F. C. E., 1996, p. 21.

37. Ibidem p. 95- 96.

Thémata. Revista de Filosofía N55 (2017) pp.: 219-248. 
estimaban por encima de todo y que, en la última centuria, a consecuencia de los juegos olímpicos, habían sido considerados, aun para los luchadores ajenos a la nobleza, como la más alta medida de la realización humana». ${ }^{38}$

Efectivamente, la idea de mérito remite tanto a la oportunidad (aquí kairós) como lo valioso que surge de la lucha, la competencia, el trasfondo agonal que lo valora. Los testimonios del periodo clásico, discursos, piezas teatrales, obras literarias o documentos epigráficos herederos de periodos anteriores (homérico y arcaico), dejan todavía en la Atenas clásica, pocas dudas acerca del interés y la importancia del deseo de sobresalir, ser el primero, y de ese modo adquirir y mantener honor, timé, y hacerse acreedor de la recompensa social, en una sociedad competitiva que considerará como de primordial importancia el reconocimiento. La moral agonística «convierte la rivalidad en un impulso poderoso configurador del comportamiento» ${ }^{39}$.

El término areté no connota sólo excelencia sino también capacidad para sobresalir. Mediante su influjo el agathós (bueno) se convierte en aristós (el mejor). Pero el kalos kagathós griego revela desde el origen la intrincada unión entre el modelo de hombre y la forma en que tanto éste como sus capacidades son valoradas. Se trata de «la imagen del hombre tal como debe ser». Para Jaeger, el origen aristocrático de la paideía explica la coincidencia en la raíz de las palabras areté y aristós (superlativo de selecto y distinguido), en una sociedad que valoraba al hombre según sus aptitudes ${ }^{40}$. Dada la íntima correspondencia entre el rango aristocrático y el sentido de ser mejor, más apto o capaz, en algunos momentos la afirmación a cada uno según sus méritos y a cada uno según su rango se propusieron como equivalentes. Esto permite la distinción entre méritos estáticos (nacimiento, rango, procedencia geográfica, etc.) y méritos dinámicos (hazañas y esfuerzos) a la que haremos referencia.

\subsection{Axiosis}

Como recordamos atrás, el significado de mérito es próximo al de valoración. La diferencia entre axiosis y axioma ${ }^{41}$ estriba en que el primer

38. Ibidem p. 96.

39. ESCOBAR, H.: Historia social del libro: Grecia I, Madrid: 1975, p. 130.

40. JAEGER, W.: Paideía. p. 21 y ss.

41. La palabra «axioma» tiene una acepción de postulado de derecho o gobierno en sentido jurídico y así la conciben la mayoría de los intérpretes. Pero como señala Jaeger, en la ciencia de Platón presenta ya un sentido hoy usual: premisa no susceptible de demostración pero que tampoco necesita ser probada. JAEGER, W.: Paideia, cit., p. 1043-1044.

Thémata. Revista de Filosofía N55 (2017) pp.: 219-248. 
término indica procesos (valoración en curso), mientras que el segundo indica un estado (dignidad, como rol o estatus social ya construido).

En un sentido más afín a nuestra moderna idea de mérito, definido éste por su desvinculación con «accidentes de origen», su condición de posibilidad es el reconocimiento de virtudes individuales en forma dinámica (desarrollo de ingenios y esfuerzos) como una axíosis que si bien según determinadas creencias pueden ser suscitadas por un dios, no depende del linaje ni -al menos en forma declarada- de la riqueza. Singularizando el estudio de Vernant al precedente griego de la actual noción de mérito como axíosis, podemos rastrearlo en un universo normativo que es aún una confusa amalgama de preceptos éticos, religiosos, políticos y jurídicos. «La relación entre individuo y mérito forma parte de la contrapartida moral que acompaña los avances del derecho» ${ }^{42}$ : la historia jurídica griega a la vez que revela el surgimiento del individuo, introduce las nociones de "responsabilidad, culpabilidad personal y mérito». ${ }^{43}$ La pertenencia de un haber a cada ser resulta decisiva en relación con la relevancia del mérito (en cualquiera de las formas anteriores) pero es cierto que hay un vastísimo periodo de tiempo anterior a las primeras polis democráticas en el cual los sujetos no se entendían a sí mismos como hómoioi, semejantes, equiparables, iguales. Esto es, un tiempo antes del término isoi, y de aquella ruptura que Castoriadis llama de las significaciones imaginarias que las instituciones encarnan e impulsan. Dicho de otra forma, hay un tiempo en el cual todavía no puede decirse que Ulises sea de ninguna manera el hómoios de Tersites ${ }^{44}$.

\section{Dos modelos meritorios en la antigüedad: hazaña y esfuerzo}

Si la forma de comprender la idea de justicia como justificación de tal o cual distribución de premios y castigos, cargos y cargas pasa por el análisis de dos parámetros -el criterio de justicia y el trasfondo competitivo- la base, el contenido vinculado a la idea de merecimientos viene determinado por el contexto sociopolítico y cultural. De esta forma evoluciona y

42. En Homero no existen aún leyes donde todo esté regulado de forma general y abstracta, y mucho menos derecho codificado. Existe una vieja polémica sobre las diferencias entre diké y Themis. De acuerdo con Glotz y Frish themis es lo recto-legal y diké lo recto-apropiado. FRISH, H.: Might and Right in Antiquity, Kobenhaun: 1949, p. 38.

43. Según Vernant, el testamento es otra prueba de la promoción social del individuo a través del derecho. Entre individuo y riqueza, cualquiera que sea su forma, bienes propios o gananciales o inmuebles, el lazo es en lo sucesivo directo-exclusivo: a cada ser pertenece un haber. VERNANT, J. P.: «El individuo en la ciudad», en Sobre el individuo, cit., p 46 y ss.

44. CASTORIADIS, C.: El ascenso de la insignificancia, cit., p. 121.

Thémata. Revista de Filosofía N55 (2017) pp.: 219-248. 
se transforma. ¿Qué base tomó en la antigüedad griega? Básicamente podríamos clasificar el contenido del ideal meritorio en ese vastísimo periodo de tiempo, en dos grandes tipos: a) Méritos dinámicos (axíosis): que tienen como base el mérito de la hazaña y el valor del trabajo que se deposita en la acción: Homero y Hesíodo, respectivamente; b) Méritos estáticos: la buena sangre o el nacimiento noble (eugeneia), la procedencia geográfica y otros.

\subsection{Méritos dinámicos}

Los principales formatos de los méritos dinámicos en la antigüedad griega son la areté heroica, un tipo de nobleza que debe ser renovada constantemente (Homero): el valor y fuerza de Aquiles; el ingenio de Ulises; la corriente arcaica que valora el esfuerzo de los Erga, el ponós, en relación con el universo del trabajo (Hesíodo).

\subsubsection{Homero y la hazaña heroica}

Tomar a Homero como el precedente educador de toda Grecia, incluso en lo que atañe a lo que venimos llamando con cierta flexibilidad «méritos» o "meritocracia antigua», resulta ineludible y se halla profundamente relacionado con el alcance posterior del origen agonal y aristocrático de la areté, y en general con los valores públicamente recompensados. Siguiendo a Werner Jaeger, Homero debe ser considerado el primero y más grande creador y formador de la humanidad griega. ${ }^{45}$ Según el historiador alemán, la pintura ideal de la poesía homérica, incluso tras la desaparición de la forma de vida de la que daba testimonio, «llegó a convertirse en el fundamento viviente de toda la cultura helénica». ${ }^{46}$ Se trata no sólo de la perduración de la obra de los poetas de la que hablara mirando idílicamente al pasado Hölderlin, sino de la unión entre ética y estética -la justificación lírica en Clifford Geertz- y su fuerza como poder ilimitado de conversión, lo que los griegos denominaban psicagogia y que trasciende la mera interiorización de las nociones de mérito y de merecimiento.

Como es sabido, la época homérica no es una época de convenciones legales reflejadas en escritos, ni de sistemas filosóficos, es una época de

45. JAEGER, W.: op. cit., p. 49.

46. Ibid. p. 52. Sobre las consecuencias de tales enseñanzas, vid., ARENDT, H., La condición humana, cit., MARROU, H. I.: Historia de la educación en la Antigüedad. Buenos Aires: Eudeba, 1965, p. 5. FINLEY, M. I.: El mundo de Ulises, Barcelona: Grijalbo, 1989, LESKI, A.: Historia de la literatura griega., México: F. C. E., 1968. RODRÍGUEZ ADRADOS, F.: Introducción a Homero. Madrid: Gredos, 1984.

Thémata. Revista de Filosofía $\mathrm{N}^{\circ} 55$ (2017) pp.: 219-248. 
tradición donde resulta extremadamente complicada la disociación entre religión, moral y derecho. A su vez, el poeta, o la tradición poética llamada Homero, parte de la unión «necesaria e inseparable» de toda poesía con el mito -el conocimiento de los grandes hechos del pasado- y de ahí deriva su función social y educadora. ${ }^{47}$ En esta época, ninguna fuente arroja un

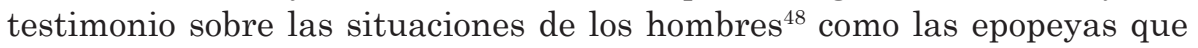
figuran bajo el nombre de Homero. Allí cabe rastrear la visión dominante del mérito, los valores que desde la moral y la justicia deben ser recompensados.

En primer lugar podemos decir que el héroe homérico es «bueno» (agathós), posee la areté, por cuanto tiene capacidad para perseguir objetivos específicos con su valor y audacia personal. Mientras la areté del caballo de carrera es la velocidad y la del caballo de tiro la fuerza, la del guerrero es su valentía, su capacidad de soportar el dolor y salvar dificultades en cualquier circunstancia, vencer a un joven en el lanzamiento del disco, despedazar y cocinar un buey y conmoverse hasta las lágrimas por una canción... Para Jaeger, «el pathos del alto destino heroico del hombre es el aliento espiritual de la Ilíada. El ethos de la cultura y de la moral aristocráticas halla el poema de su vida en Iliada y Odisea. La sociedad que produjo aquella forma de vida tuvo que desaparecer sin dejar testimonio alguno de su conocimiento histórico. Pero su pintura ideal, incorporada a la poesía homérica, llegó a convertirse en el fundamento viviente de toda la cultura helénica». ${ }^{49}$ En los siguientes versos Héctor implora por el reconocimiento de la superioridad de su hijo frente a los demás guerreros. No ruega para que su hijo obtenga el botín sino para que mediante su valentía promueva el reconocimiento de su propia excelencia: «iZeus y demás dioses. Concededme que este hijo mío sea, como yo, ilustre entre los teucros y muy esforzado; que reine poderosamente en Ilión; que digan de él cuando vuelva de la batalla: jes mucho más valiente que su padre!; y que, cargado de cruentos despojos del enemigo a quien haya muerto, regocije de su madre el alma».

La hazaña del guerrero no es íntima: necesita del reconocimiento del otro. La recompensa significa que alguien sepa de su excelencia y la promueva: «No quisiera morir cobardemente y sin gloria sino realizando algo grande». ${ }^{50}$ De aquí viene ese deseo apasionado de gloria, de ser pro-

\section{JAEGER, W.: op. cit., p. 53.}

48. Sobre esta subjetividad, vid., LLINARES J. B. «¿Son verdaderos 'sujetos' los seres humanos de la Grecia arcaica? Notas en torno a la interpretación de la Antropología homérica» en SANFÉLIX, V.: Las identidades del sujeto. Valencia: Pre-Textos, 1997, 23-57.

49. JAEGER, W.: op. cit., p. 52.

50. HOMERO: Ilíada, 476, versos similares en 304- 305, 221 - 245.

Thémata. Revista de Filosofía $\mathrm{N}^{\circ} 55$ (2017) pp.: 219-248. 
clamado el mejor, impulso fundamental de esta moral caballeresca: el héroe homérico no es realmente feliz si no se afirma como el primero dentro de su categoría. Como escribía Adkins, el guerrero no es virtuoso o meritorio por sus intenciones, sus acciones deben ser juzgadas por sus resultados. En Homero lograr algo significa sobresalir, pero también ganar. El agón es el concurso formal y reglamentado que articula esta relación propia del contexto guerrero. La épica en la que se educa el ciudadano antiguo dibuja un ideal donde importa sobresalir. Cada cual debe ser comparado con los otros. El héroe no está conforme si no se siente superior a los demás. Ser superior implica gozar del favor de los dioses y decidir sobre los actos de los demás, como cuando Héctor dice a Aquiles: «Tu eres poderoso pues tu madre es una diosa, pero Agamenón es más valioso porque domina sobre los demás». ${ }^{51}$

Los personajes del universo homérico no se conforman con desarrollar una acción con entusiasmo y eficacia: el arquetipo agónico, el modelo del guerrero que compite por el botín, deja una impronta en la cultura esencialmente aristocrática en el concepto de areté. De lo que se trata efectivamente no es de ser bueno sino de ser el mejor. En el Canto XI de la Ilíada Néstor cuenta cómo Peleo aconseja a su hijo ser aristeuein y quedar por encima de los otros. ${ }^{52} \mathrm{El}$ trasfondo agonal representa el espacio de acción donde se reconoce el mérito del hombre fuerte (Aquiles) o de ingenio (Ulises).

El héroe de las tragedias griegas sufre el destino como castigo, y aunque éste escapa a su voluntad, acaba entendiéndolo como merecido pues sus acciones han alterado el orden natural del cosmos. ${ }^{53}$ La acción y el efecto de merecer traspasan el terreno de lo religioso y lo político. Íntimamente vinculado con la areté se halla, pues, el honor, que en los primeros tiempos era inseparable de la heroicidad, la valentía, la habilidad cuando el hombre homérico adquiera exclusivamente conciencia de su valor por el reconocimiento, siendo el elogio y la reprobación (epaínoslfoghos), fuentes de honor y deshonor. También Jaeger en Paideía recuerda que entre los griegos no hay concepto alguno parecido a nuestra conciencia personal en la indagación sobre la verdadera responsabilidad, sólo elogio y reprobación. Así lo ve E. R. Dodds, esto es, condicionado por el aidós... «la situación a que responde la noción de ate surgió, no meramente del carácter impulsivo del hombre homérico, sino de la tensión entre el impulso individual y la presión de la conformidad social característica de una cultura de vergüenza. Todo lo que expone a un hombre al desprecio o a la

51. HOMERO: Ilíada, Cantos, 280 y 281.

52. HOMERO: Ilíada, IX, 784.

53. PIULATS, O.: Antígona y Platón en el joven Hegel, Barcelona: Integral, 1985. Sobre la individualización de la culpa, relación entre mito y monoteísmo en el origen de la igualdad; REYES MATE M.: Pensar la igualdad y la diferencia. Una reflexión filosófica, 1995, pp. 77.

Thémata. Revista de Filosofía N55 (2017) pp.: 219-248. 
burla de sus semejantes, todo lo que hace quedar avergonzado, se siente como insoportable». ${ }^{54}$

El contexto agonal lo abarca todo. Nadie teme en la Antigüedad reclamar honor, pero «la exigencia de recompensa adquiere un punto de vista subalterno y en modo alguno decisivo». ${ }^{55}$ La perspectiva de la justicia como díke, themis, como normas que rigen las conductas debidas es un orden agonal, con sentido de lo justo, dikaiosyne: sumisión a la excelencia del mejor o grupo de mejores. Homero dubuja al grueso del ejército desaprobando enérgicamente el sedicioso discurso de Tersites cuando éste cuestiona el reparto del botín, aplaudiendo, riendo cuando el gran Odiseo le golpea en la espalda y en los hombros con su áureo cetro, obligándole a sentarse otra vez, entre lamentos. ${ }^{56}$ Homero caricaturiza al discurso reivindicativo de Tersites "parlanchín sin juicio», como propio de un hombre irrefrenable a quien, si le venía en ganas acosar a sus reales amos, no le faltaba nunca un chiste vulgar, vano y procaz, calculado para hacer reír a la tropa. Y también como «el hombre más indigno llegado al pie de Troya; era patizambo y cojo de una pierna; tenía ambos hombros encorvados y contraídos sobre el pecho, cabeza picuda, y encima rala pelusa floreaba. Era el más odioso sobre todo para Aquiles y para Ulises a quienes solía recriminar...».57

Otro episodio de lucha por el mérito lo ofrece el juicio de las armas de Aquiles que los aqueos deciden entregar al mejor de los héroes. Aquel donde, como recuerda García Gual, «cada uno de los dos caudillos expone sus méritos y critica los del otro». ${ }^{58}$ Por otra parte, sobre el mérito de Agamenón y siguiendo a Arendt, el criterio de justicia para el posterior uso del botín presupone el mérito del principiante de la acción: «La fuerza del principiante se muestran en la iniciativa [...] no en la verdadera realización. En el caso del gobernante con éxito, reclama para sí lo que realmente es el logro de muchos, [...] el gobernante monopoliza la fuerza de aquellos sin cuya ayuda no hubiera podido realizar nada.». ${ }^{59}$

\subsubsection{Hesíodo. Pónos el mérito del esfuerzo}

No resulta forzado proponer a Hesíodo como el más antiguo difusor del mérito del esfuerzo canalizado en el trabajo cuyo eco resuena, con todas sus variantes, desde la sanción del trabajo duro y el sufrimiento en

54. DODDS E. R.: Los griegos y lo irracional, Madrid: Alianza, 1980, p. 28-31.

55. JAEGER, W.: op. cit., p. 25.

56. HOMERO: Ilíada II, 265-278.

57. HOMERO: Ilíada II, 212, 244 -246.

58. GARCIA GUAL, C.: La secta del perro, Madrid: Alianza, 1998, p. 39.

59. ARENDT, H.: La condición humana, cit., p. 213.

Thémata. Revista de Filosofía $\mathrm{N}^{\circ} 55$ (2017) pp.: 219-248. 
el cristianismo, Locke, la ética puritana, las ideologías empleocentristas surgidas con el trasfondo de la revolución industrial hasta nuestros días. Forma de legitimar moralmente la expectativa a ver recompensados los frutos obtenidos por el pónos, el esfuerzo ${ }^{60}$ se configura en la lírica de Hesíodo como una peculiar forma de areté, una manera de desarrollar aptitudes valorables, que son para el poeta, verdaderamente humanas, y en la que el derecho o mejor el nomos debe hallarse en el centro de la vida. ${ }^{61}$

Hesíodo de Ascra, contemporáneo de las primeras colonizaciones griegas de la época arcaica y de la consolidación del estado aristocrático se sitúa en el inicio de dos líneas de pensamiento relacionadas con el sentido de lo justo. Respecto al mérito, se le puede considerar como el más antiguo defensor del esfuerzo, pónos. Según esta idea, el hombre merece los resultados obtenidos sobre la base de su sacrificio en el trabajo. Lo resume perfectamente Jaeger: «El trabajo es ensalzado como el único, aunque difícil camino para llegar a la areté. El concepto abraza al mismo tiempo la destreza personal y lo que de ella deriva -bienestar, éxito, consideración-.. ${ }^{62}$ $\mathrm{Al}$ mismo tiempo, para Hesíodo la justicia define el ámbito de lo humano. En lo que aquí nos interesa, podríamos decir que Hesíodo muestra una sensibilidad frente al mérito distinta a cómo aparecerá en la lírica gnómica y en general en el pensamiento aristocrático. Hesíodo se distancia de la visión predominante de los valores en las fuentes educacionales arcaicas: ya no se trata de la areté guerrera de la antigua nobleza, ni de la clase propietaria, fundada en la riqueza, sino la del hombre trabajador que halla su expresión en una posesión moderada. Es la palabra central de la segunda parte, los Erga propiamente dichos: su fin es la areté, tal como la entiende el hombre del pueblo. Quiere hacer algo con ella y prestarle una figura. Parece que el contexto agonal desaparece, pero resulta que más bien se transforma: «En lugar de los ambiciosos torneos caballerescos, exigidos por la ética aristocrática, aparece la silenciosa y tenaz rivalidad del trabajo. Con el sudor de la frente debe ganar el hombre su pan. Pero esto no es una maldición, sino una bendición. Sólo a este precio puede alcanzar la areté». ${ }^{63}$ Tras el Proemio, Hesíodo plantea en Las Dos Érides, el agón del esfuerzo para sobresalir en trasfondo del agón.

A la otra primogénita la engendró la tenebrosa noche y Zeus [...] la colocó en las raíces de la tierra y es más provechosa para los hombres; ella despierta para el traba-

60. GERNET, L.: Antropología de la Grecia Antigua, Madrid: Taurus, 1981. MARTINEZ DÍEZ, A.: Hesíodo, obras y fragmentos, Madrid: Gredos, 1978. De las diferencias en ese ideal VERNANT, J. P.: Mito y sociedad en la Grecia antigua, Madrid: Siglo XXI, 1982.

61. JAEGER, W.: op. cit. pp. 67-83.

62. JAEGER, W.: op. cit., p. 78.

63. JAEGER, W.: op. cit., p. 79.

Thémata. Revista de Filosofía $\mathrm{N}^{\circ} 55$ (2017) pp.: 219-248. 
jo incluso al muy holgazán, pues está ansioso de trabajo cualquiera viendo a otro rico que se apresura a cultivar, plantar y disponer la casa; el vecino envidia al vecino, [...] el pobre envidia al pobre y el aedo al aedo.

Su conocimiento directo del sufrido esfuerzo le hizo proclamar que lo peor de la pobreza es la incomprensión del que la padece: «Es la pobreza lo que es malo y no el que la sufre» ${ }^{64}$. El mismo padre de Hesíodo, según nos cuenta éste, sintió la urgencia de la escasez frente a la tranquilidad que da la riqueza. ${ }^{65}$ En la época que Hesíodo escribe Trabajos y días, esto es o comienzos del VII a. de C. el acceso al poder político era disfrutado por un tipo de aristocracia hereditaria a la que define como «príncipes devoradores de regalos» burladores de la justicia, emisores de sentencias torcidas. Hesíodo apela a la Díke en su lucha contra la avaricia de su hermano.

Pero «los Trabajos y días trazan también un cuadro de corrupción moral. Incluso los lazos de sangre en los que descansaba el antiguo dominio de los nobles ya no tiene vigencia; cada individuo busca sin reparo su propio provecho y la fuerza priva sobre la justicia y la fidelidad. En tales tiempos, el duro trabajo del campesino prudente, que gana al suelo la propia existencia, adquiere una nueva significación y dignidad. Dependiendo sólo de sí mismo, también puede mantenerse solo cuando todo se desploma». ${ }^{66}$ En efecto, aunque los dioses, la naturaleza y los hombres poseen los elementos para el buen funcionamiento de un mundo ordenado por Zeus: Eris (emulación), areté (virtud, excelencia en un ámbito práctico) y aidós (respeto), también tienen junto a estos bienes algunos males, entre los que destaca el ocio, que aparece como el mayor delito social, por lo que, cuando éste perturba el orden debe actuar Zeus garante de la justicia y restablecer el equilibrio. La corriente que refleja Hesíodo significa la valoración del esfuerzo frente al ocio: el pónos. "Nada reprochable es el trabajo, muy reprochable es la inactividad. Pero si trabajas rápidamente, el hombre inactivo te envidiará a ti que te enriqueces, pues éxito y prestigio acompañan a la riqueza». ${ }^{67}$ La guerra trae insidiosa discordia; el trabajo, en cambio, representa una lucha buena para los hombres. Poseerá areté todo aquello que demande un considerable esfuerzo, ya que delante del mérito pusieron los dioses mortales el sudor. Moralmente hay una diferencia esencial: las relaciones humanas quedan sometidas a la justicia (dike), protegidas al amparo de Zeus garante. En contraste con Teognis, al que veremos diri-

64. HESÍODO: Trabajos y días, 633-637.

65. HESÍODO: Trabajos y días, 633-637.

66. FRÄNKEL H.: Poesía y Filosofía de la Grecia Arcaica, Madrid: Visor, 1993, p. 120.

67. HESÍODO: Trabajos y días, 310-315.

Thémata. Revista de Filosofía Nº55 (2017) pp.: 219-248. 
giendo sus consejos a la clase superior, el hombre de Hesíodo se mantiene dentro del horizonte de lucha por el sustento cotidiano.

\subsubsection{La valoración democrática de la axíosis}

En época de Pericles el discurso eugenésico sigue presente en los representantes aristocráticos, asimismo, el discurso del «hombre fuerte» ${ }^{68}$ cuyo paradigmático defensor, Calicles, sobrevive en el Gorgias platónico, siguiendo a Dodds o a Guthrie, prefigurando el superhombre (Übermensch) de Nietzsche. ${ }^{69}$ Pero esta época es, sobre todo, la del discurso democrático e igualitario. Doménico Musti en su estudio sobre los orígenes de la idea de democracia muestra cómo Pericles, habría defendido un concepto dinámico de la valoración social. Pericles a la vez que exalta el ejercicio del derecho a la participación política activa de todo aquel que tenga capacidad para ello, garantiza también un estatus sólido a la persecución legítima de los fines privados: ${ }^{70}$

Según la valoración (axiosis) ${ }^{71}$, según el crédito que consiga en una actividad, no se le prefiere por la riqueza más que por sus méritos (aquí su "excelencia", "virtud" areté), ni se ve obstaculizado por su estatus social (axioma), si es capaz de prestar un buen servicio a la ciudad.

En este sentido, la axíosis presenta una perspectiva democrática del concepto de mérito desde la meritocracia en sentido etimológico, como proceso en curso de formación que es el reconocimiento de la recompensa social que cada cual conquista. Frente al axioma, prestigio fundado, mérito estático y cerrado encontramos el carácter dinámico de la axiosis. Se trata de la aportación característica de la democracia respecto a la valoración de la persona, su rol social y su mérito, como consecuencia de la igualdad frente a la ley que se hace valer como principio positivo en la esfera de diversidades o divergencias privadas reequilibradas por el nómos, principio público de la igualdad. El mérito se dinamiza, se abre a aquellos reconoci-

68. Según Calicles, en Gorgias, los derechos son promulgados por hombres débiles, esto es, la mayoría para su propio provecho, protegiéndose de las aptitudes de los fuertes. PLATÓN, Gorgias, 483c. PLATÓN, República, I, 338c -348c. Un estudio sobre Trasímaco, la justicia y su función RUS RUFINO, S., MAEBE, E.: Justicia, Derecho y fuerza, Madrid: Tecnos, 2001.

69. Aunque Nietzsche no menciona a Calicles, esta tesis la defiende DODDS, E. R.: Gorgias, Oxford: 1959, p. 389 «Nietzsche tiene en mente la imagen de Calicles o Trasímaco». PLATÓN, Gorgias, 429d. GUTHRIE, W. K. C.: Historia de la filosofía griega, vol. IV, Madrid: 1990, p. 113 habla de Nietzsche como de «un hermano de sangre de Calicles».

70. MUSTI, D.: Demokratía. Orígenes de una idea, cit., p. 83.

71. ALLISON, J. W.: «Axíosis, New Arete: A Periclean Metaphor for Friendship», cit. p. 53.

Thémata. Revista de Filosofía $\mathrm{N}^{\circ} 55$ (2017) pp.: 219-248. 
dos iguales en tanto que ciudadanos. Sobre el definitivo carácter dinámico del tipo de méritos que reconoce la polis democrática: «El aspecto procesual y la renovación de vez en cuando de la valoración del mérito (hos hékastos én toi eudokimê̂) expresan mejor que cualquier otra consideración el aspecto democrático de la axísis.» ${ }^{72}$

\subsection{Méritos estáticos}

La sublimación del mérito eugenésico, su expresión lírica más elaborada, coincide con el inicio de la democratización de las polis, la reducción del basileus a la categoría de magistratura anual por elección, y junto a ello, la reacción de la aristocracia que apela al linaje frente al pueblo y las nuevas fortunas generadas por el comercio. En efecto, la nobleza desborda la posición que habían ocupado los poderosos de la época homérica y se defiende de la movilidad social apelando a su mejor aptitud, educación y hechos del pasado que merecen ser recompensados también en los descendientes de la misma sangre. Los aristócratas han disfrutado en nombre del mérito eugenésico de numerosos privilegios jurídicos: los más aptos por linaje y educación (asociada al linaje) merecen los principales cargos y prerrogativas. Ante el inicio de fórmulas democráticas, los linajes englobados bajo el nombre de eupátridas ("descendientes de padres ilustres») ven peligrar sus prerrogativas. Es entonces cuando se enfatiza el demérito del trabajo como sujeción a las necesidades: el trabajo se presenta líricamente como algo que degrada y envilece.

\subsubsection{Nobles y advenedizos: Teognis}

La sujeción al trabajo significa menor aptitud para el kratos, a veces su falta absoluta y se denuncia, desde las fuentes aristocráticas, como estorbo para ostentar cargos públicos. Los aristócratas pretenden que el requisito fundamental para gobernar sea el linaje, la posición noble merecida por acciones pretéritas. Los descendientes esgrimen la procedencia de la «buena familia», familias ricas educadas en la virtud y no comerciantes enriquecidos que carecen de ella. Los eupatridas dicen merecer los cargos por su origen y por las aptitudes heredadas como grupo. Aunque la posición preponderante de la nobleza depende de su riqueza y de su experiencia en el gobierno, el noble se eleva frente al pueblo también por otros méritos, su conocimiento del derecho, su capacidad cultural, deportiva y

72. MUSTI, D.: Demokratía. Orígenes de una idea, cit, p. 119.

Thémata. Revista de Filosofía $\mathrm{N}^{\circ} 55$ (2017) pp.: 219-248. 
musical. El aristócrata quiere que el pueblo le tenga como interlocutor natural: presenta una cosmovisión conmovedora de su propio poder, quiere educar al pueblo con una imagen de sí y del mundo que haga esa desigualdad deseable. El mérito de la buena cuna y el abolengo defendido, bien por los propios interesados, bien por sujetos del círculo social del que extraen ventajas sociales, se expresa en un lenguaje normalmente polarizado eugeneis y gennaioi frente a la "turba" (okhlos), los inferiores (poneroi) o los peores (kheirous).

La lírica gnómica y la recepción en círculos privilegiados del mérito como distinción frente al pobre o el plebeyo es la más clara exposición de la ideología meritocrática en su versión aristocrática, para la cual la areté, excelencia, o virtud es cosa heredada, inenseñable, propia sólo del hombre noble distinguido por el mérito eugenésico del linaje, que es el bueno (agathós), mientras que el hombre del pueblo como hombre pobre es el malo (kakós) y sin mérito reconocible. Pero, además, el primero es justo (dikaios), el segundo tiene hybris. Y ello porque pretende abolir las diferencias que en la ideología aristocrática se definen como naturales. En numerosos lugares es posible encontrar una reacción ante los cambios que el dinero introduce en la valoración social. De la lírica de Lesbos de la que procedía también Safo, Alceo «[...] recomienda sumisión al destino que a cada uno es concedido en su nacimiento». ${ }^{73}$ Otra vez deplora Alceo que los hombres cifran el valor de alguien no en su persona sino en sus bienes: «... Una vez en Esparta Aristodemo dijo algo agudo: / El hombre es el dinero. Ningún necesitado es respetado y digno...»

Por otra parte, sobre una clase inferior en la poesía arcaica, los yambos de Hiponacte buscan sus héroes grotescos entre gente ordinaria, los advenedizos son ridiculizados por Arquiloco, Anacreonte, Píndaro y Teognis vuelven a defender a la nobleza frente a la simple riqueza, con Jaeger ambos se hallan "penetrados de una profunda conciencia de clase», en opinión de Fränkel, los dichos de la colección de Teognis están dirigidos a la clase superior. ${ }^{74}$ Dentro del juego de opuestos polarizados, algo constitutivo del pensamiento primitivo griego y especialmente en el periodo arcaico $^{75}$, Teognis de Mégara el poeta que escribió entre el siglo VII y el VI a. de C. describe una sociedad dividida en dos grupos denominados según esa terminología que era ya una mezcla inseparable de conceptos morales y sociales: los buenos (agathoi o esthloi) y los malos (kakoi o deiloi). Se abomina de la pobreza: condiciona incluso la posibilidad de comprenderla y la

73. ALCEO: Fr. 142. EURÍPIDES: Electra 376 ss. RODRIGUEZ ADRADOS, F.: Líricos griegos. Elegíacos y yambógrafos arcaicos. II, Madrid: Alma Mater, 1990, pp- 27-120.

74. FRÄNKEL H.: cit. p. 492.

75. RODRÍGUEZ ADRADOS, F., Democracia y literatura en la Atenas clásica, cit.

Thémata. Revista de Filosofía $\mathrm{N}^{\circ} 55$ (2017) pp.: 219-248. 
libertad de expresión: "A un hombre virtuoso es la pobreza lo que más le somete a su poder, más que la cana vejez y que la fiebre, oh Cirno; por huir de la cual hay que arrojarse al mar, poblado de grandes monstruos, [...] un hombre que está en poder de la pobreza, no puede decir ni hacer nada: su lengua está encadenada ${ }^{76}$. Los buenos deben gobernar sobre los mejores, los primeros reúnen aptitudes y destrezas que los hacen aptos para decidir sobre cuestiones comunes, entre ellas recibir la herencia de antepasados ilustres que lograron notoriedad por hazañas o aportaciones al bien común. Los eupátridas temen que las reformas políticas olviden estos hechos y entre otras consecuencias les hagan perder su estatus económico.

En un período de decadencia de la aristocracia, Teognis aristócrata desterrado, expone el lamento del hombre privado de riquezas y de «calidad» (mérito) de hombre superior que comprueba los efectos exteriores de la escasez e incluso puede asomarse, entre estos efectos, a las limitaciones que tiene el pobre para expresarse. ${ }^{77}$ Lo que está en peligro es el olvido de las desigualdades de talento. Teognis al igual que Píndaro educan a través de máximas morales en apoyo de la amenazada supremacía del grupo alto. Para ellos no sólo no debía predicarse de los hombres la igualdad, sino en lo que nos interesa aquí la pretensión del pueblo de una mayor igualdad es $h y$ bris, un exceso contrario a la justicia. «La única posibilidad de salvación es la vuelta a la justa desigualdad y al dominio de los nobles». ${ }^{78}$ En opinión de Fränkel, Teognis abandona en cierto momento su convencimiento aristócrata para convertirse en un "oportunista». ${ }^{79}$

La clase alta para Teognis, es alta tanto por su talento como por su origen noble, y ambos están asociados: antídoto vitalicio contra la inseguridad a que la vida convulsionada entrega a los pobres, el mérito nobiliario viene caracterizado por la tenencia, entre otros, rasgo, de valor, aidós o respeto, superior inteligencia y sobre todo excelencia (aretê): «Hay muchos malvados que son ricos mientras los buenos son pobres; pero nosotros no les cambiaremos nuestra virtud por su riqueza, porque la primera dura mientras que los bienes de fortuna los posee ora uno, ora otro». ${ }^{80}$

En el debate sobre si esta areté era una cuestión de talento natural o podía adquirirse por la enseñanza Teognis tipifica la idea de un talento natural solo predicable de un grupo en particular que pretende hacer de

76. TEOGNIS, I. 173-182 RODRÍGUEZ ADRADOS, Líricos griegos. II, cit. p. 180, nota. 1. 77. ALCEO: 50 y PÍNDARO: Istmicas, 2, 11, en RODRIGUEZ ADRADOS, F.: Elegíacos y yambógrafos arcaicos, cit., p. 178, n.4, y 180-181 n. 3

78. JAEGER, W.: op. cit. p. 190.

79. FRÄNKEL, H., Poesía y filosofía de la Grecia Arcaica, cit. p. 380.

80. TEOGNIS: I, 315-319.

Thémata. Revista de Filosofía №55 (2017) pp.: 219-248. 
los términos «bueno» y "noble» sinónimos: ${ }^{81}$ "Bebe y come con aquellos, reúnete con aquellos y sé grato a aquellos cuyo poderío es grande. De los buenos aprenderás cosas buenas; pero si te juntas con los malos, estropearás incluso tu buen natural». ${ }^{82}$ Rodríguez Adrados hace notar que se exige la posesión de un buen natural: «No es posible la educación de la clase inferior, pero sí la perfección o corrupción de la superior». ${ }^{83} \mathrm{El} \mathrm{mismo}$ pensamiento se repite más adelante: «Es bueno ser invitado a un banquete y sentarse junto a un hombre de calidad». ${ }^{84}$ Contrario a la potencial capacidad de confusión de la mera riqueza sin linaje, Teognis es uno de los primeros críticos de los nouveaux riches. Incluso su odio a los tiranos puede comprenderse en este sentido: permiten el ascenso social de nuevas clases enriquecidas que de otra forma, esto es por el "buen linaje" no lo hubieran conseguido $^{85}$.

No se trata tan sólo de una ideología: también de circunstancias que envuelven al poeta. Este odia al "pueblo insensato», como rechaza también la tiranía. «Pero lo que más le duele son los hombres enriquecidos, que se casan con mujeres de la aristocracia, mientras que los nobles y el propio Teognis son pobres» ${ }^{86}$.

\subsubsection{Sobre el axioma como valor estático: ergon y deporte}

Encajan aquí el mérito «orgánico», estático o heredado de la aptitud aristocrática frente al pobre y frente al súbitamente enriquecido, basada la eugeneia por la cual el bien nacido es titular de un mérito: el imaginario aristocrático. Otros méritos estáticos son la procedencia geográfica, raza, «fuerza natural» y género: frente al extranjero ${ }^{87}$ (meteco), el débil, la mujer y el esclavo

81. W. K. C. GUTHRIE: op. cit. p. 40.

82. TEOGNIS: I, 31-37.

83. RODRIGUEZ ADRADOS, F.: Elegíacos y yambógrafos arcaicos (cit. Para Rodríguez Adrados Teognis no se resigna a la separación entre riqueza y areté).

84. TEOGNIS, I, 564-565.

85. RODRIGUEZ ADRADOS, F., Historia de la democracia, de Solón a nuestros días, Madrid, Temas de Hoy, 1996, p. 77.

86. RODRIGUEZ ADRADOS, F.: Ibid., cit. p. 78.

87. STE CROIX, G.: La lucha de clases en el mundo griego antiguo, cit.; RODRIGUEZ ANDRADOS, F.: La democracia ateniense, Madrid: Alianza, 1995,.

Thémata. Revista de Filosofía $\mathrm{N}^{\circ} 55$ (2017) pp.: 219-248. 
(al que Zeus ha despojado de parte de su areté). ${ }^{88}$ En un cosmos armonioso donde cada cual cumple con un rol asignado en la estructura, lo bueno (agathós) será conocer y respetar el lugar de cada uno. En la polis cada cosa, casa y persona tienen un rol (ergon) determinado. Así como el alma tiene una función que le es propia ("mandar, gobernar, deliberar») ${ }^{89}$ aquello que puede hacer mejor, así como la función del ojo es ver, cada ser humano tiene una función particular que puede cumplir mejor que cualquier otro. Platón hará decir a Menón que hay «una virtud propia de los niños de uno y otro sexo y otra propia de los ancianos, una que conviene al hombre libre y otra al esclavo; en una palabra, existen virtudes diversas en número infinito». ${ }^{90}$ Cada ergon tiene su virtud propia. La polis hereda de este modo un fuerte sesgo organicista del contexto homérico. Ulises ya se jactaba de saber combatir y confesaba su aversión por el trabajo manual al afirmar: "Yo era hábil en la guerra; el trabajo, en cambio, no me agradaba». ${ }^{91}$

Homero distingue el ergon del artesano, del sacerdote, del adivino, del intérprete de sueños y del labrador. Cuando el consejero militar Polidamas procura que Héctor adopte su estrategia dice: «A unos Dios les ha asignado un ergon bélico, a otros la danza y a otros la lira y el canto; a otros, en fin, les ha puesto Zeus en el pecho una comprensión o una percepción sensata». ${ }^{92} \mathrm{Si}$ bien en el contexto posterior de la polis todos los ciudadanos pueden formar parte de tribunales y asambleas, respondiendo a leyes escritas que reemplazan a la prueba de la fuerza, las más altas magistraturas sólo están disponibles en esta época preclásica para quienes son considerados mejores por linaje y riqueza. La riqueza es meritoria en un momento en el que la propiedad territorial como subrayaba Ste Croix estaba distribuida en forma desigual..$^{93}$ Por otra parte, el perímetro de los iguales excluye al esclavo y a la mujer de la dignidad ciudadana. La principal virtud de ambos será obedecer. La mujer administrará bien su casa,

88. FINLEY, M.: Esclavitud antigua e ideología moderna, Barcelona: Crítica, 1982. Sobre el demérito del esclavo: «...Zeus toma la mitad de la areté cuando le sobreviene al esclavo el día de la sujeción... Ante la ausencia formal de esta libertad existe algún ingrediente que empuja hacia abajo a un hombre -en sí mismo capaz- de forma que ya sólo conserva la mitad de todo sus méritos. Ante esta idea no hace falta un gran salto para pasar a la opinión posteriormente reinante, que ve a los esclavos a individuos que, sin más, desmerecen». GSCHNITZER, F.: Historia social de Grecia, op. cit. p. 120 y ss.

89. PLATÓN: República, 352 e.

90. PLATÓN: Menón, 71e.

91. HOMERO: Odisea, Canto XIV, 222.

92. HOMERO: Ilíada, 730.

93. También VERNANT, J.P.: Los orígenes del pensamiento griego, cit., p. 73.

Thémata. Revista de Filosofía $\mathrm{N}^{\circ} 55$ (2017) pp.: 219-248. 
obedecerá a su marido, será bella, casta, fiel y tejerá con habilidad. Sus virtudes serán silenciosas. Es a los hombres a quienes corresponde hablar.

Acerca de la conexión entre aristocracia y mérito deportivo, apenas hay espacio aquí para mencionar algunas cuestiones relativas a la gesta atlética según la describió Píndaro. La repercusión pública en forma de honores debidos a la acción deportiva es visible en sus Olímpicas. Rodríguez Adrados subraya las exigencias aristocráticas del periodo en el que aparecen los Epiniceos y en general en la obra de un poeta que representa para la lírica una cima análoga a la de Homero para la épica. ${ }^{94} \mathrm{El}$ poeta de Cinoscéfalas pertenece a una familia aristocrática adinerada, los Egeidas. Su juventud coincide con la decadencia del sistema aristocrático al calor del nuevo régimen democrático. Su relación con los círculos selectos y el clima de abundancia y ostentación de las cortes de Siracusa o Acragante contribuye al entramado simbólico de Píndaro. ${ }^{95}$ Así, encontramos en la Olímpica II el deseo de que el poder sea conservado por los descendientes de Terón, tirano de Acragante, con argumentos que apelan a la relación entre riqueza y mérito, virtudes generadoras de riqueza: «[...] es a Terón a quién debemos celebrar por su cuadriga victoriosa, hombre justo por la observancia de la hospitalidad, [...] La vida que el destino les marcó les fue propicia y les ofreció riqueza y esplendor en premio a sus legítimas virtudes». ${ }^{96}$ Los participantes en las pruebas solían pertenecer a clases poderosas, que eran en realidad las que podían correr con los costosos gastos del entrenamiento, cuadras, carros, etc. Prueba de ello son los destinatarios de los poemas, con frecuencia señores de las cortes de Sicilia y Magna Grecia, que consideraban rentable políticamente, en relación con sus súbditos, la inversión que suponía participar en los juegos. Los beneficios derivados de una victoria eran considerables, no sólo desde el punto de vista político, sino también por los privilegios económicos y sociales con que la ciudad solía recompensar a los ganadores: «esa superioridad debe conducirle al éxito, que no sólo se demuestra en ese tipo de triunfos, sino en el poder político y en una posición económica acaudalada para permitir el dispendio y la esplendidez». El poeta conduce a la oda al pasado mítico, que sirve de paradigma de la acción presente y que relaciona al atleta con

94. BÁDENAS, P.: Píndaro. Epinicios, Madrid: Alianza, 1984, p. 11 y ss. ORTEGA, A.: Píndaro. Odas y fragmentos, Madrid: Gredos, 1984. SUÁREZ DE LA TORRE, E.: Píndaro, Madrid: Cátedra, 1988. ALSINA, J.: Píndaro. Epinicios, Barcelona: PPU, 1988.

95. PINDARO: Epinicios, cit., p. 10.

96. PÍNDARO: Olímpica II, 8-14 (Cursiva nuestra).

Thémata. Revista de Filosofía $\mathrm{N}^{\circ} 55$ (2017) pp.: 219-248. 
las gestas de la saga, como demostración de la continuidad de la gloria o del mérito eugenésico propio de las familias aristocráticas, objeto del canto.

\section{Otros méritos: hombre sabio y «mérito» en Aristóteles}

\subsection{República como meritocracia: un apunte}

De forma muy esquemática y en el limitadísimo propósito que nos ocupa aquí, podemos decir que para Platón el gobierno debería constituir la prerrogativa de quienes poseen determinadas condiciones, una phisis extraordinaria, atributos intelectuales apropiados (autodominio, prudencia, sensatez o armonía con uno mismo), educación filosófica adecuada y un modo de vida noble y excelente. ${ }^{97}$ Fue, quizás en sentido estricto, el primer filósofo que formuló una teoría sobre la organización del cuerpo político - el estado- a partir de una educación compatible con esa organización. Sus ideas reunidas en República, son a la vez políticas y pedagógicas. Le preocupa la administración y control de las conductas y esa preocupación lo lleva, como es bien sabido, a un modelo de organización política cuyo acento es el orden y control de tres grupos sociales: gobernantes, guardianes y ciudadanos. En esa comunidad utópica, la virtud capital, la justicia, consiste en que cada sujeto cumpla con la misión que tiene asignada dentro de su estamento social. Hay un paralelismo en su división del alma humana y de la sociedad: los magistrados son el elemento racional de la ciudad, y por ello son los encargados de dirigir la actividad social. Su virtud es, igual que en el caso del individuo, la prudencia. Los guerreros son el elemento emocional. Su virtud, el valor, ha de ser puesta al servicio del bien común, cuya interpretación corresponde a magistrados y gobernantes. Los productores constituyen el elemento apetitivo del estado, y su misión es producir bienes materiales. La virtud que ha de caracterizarlos, la moderación, consiste en someterse a los dictados de la clase gobernante: la razón. Platón establece, como es sabido, una virtud específica para cada grupo social: la virtud de los gobernantes es la sabiduría; la de los guardianes, la fortaleza; la de los ciudadanos, la templanza. La sabiduría-filosofía es atributo exclusivo de los gobernantes: deben seleccionarse por su fidelidad al bien público. ${ }^{98}$

La función educadora implica selección y formación con un profundo

97. PLATÓN: Carta VII, 326c. Sobre otras implicaciones de la Carta VII, vid., BARES, J. D., “Sabiduría y enseñanza en la Carta VII de Platón”, $\Delta \alpha \mu \omega \nu$ 4, 1992, pp. 19 - 40.

98. PLATÓN: República, II, 39

Thémata. Revista de Filosofía $\mathrm{N}^{\circ} 55$ (2017) pp.: 219-248. 
sentido éticopolítico. No prescribe ninguna educación especial para la clase inferior, pero sí minuciosamente la que se debe dar a los encargados de las funciones defensivas y rectoras (recordemos que le interesa sobre todo evitar las causas de la desunión de la clase gobernante, factor fundamental en la degeneración de los regímenes políticos). Los guardianes deben quedar exentos de cualquier oficio manual, para poder dedicarse plenamente a su preparación en las funciones de defensa y gobierno. El objetivo último de la educación no es simplemente el conocimiento, sino su práctica. El sistema educativo constaría de tres ciclos, durante el desarrollo de los cuales se selecciona hasta llegar a la formación de una élite. Platón habría confiado todos los poderes públicos a los hombres que, en su opinión, se hallaban intelectualmente cualificados para gobernar y hubieran recibido una educación filosófica completa. Esta es la esencia de la prescripción platónica consecuente con su teoría de la naturaleza humana. ${ }^{99}$ La "meritocracia» de Platón sería pues, el gobierno de los mejores, siendo estos aquellos hombres que administran a los gobernados por su inteligencia y pericia. Bobbio verá en la afirmación de Platón, un precedente del problema de la relación entre el gobierno «de los hombres» y el gobierno «de las leyes».

El filósofo resuelve esta elección a favor del primero que gobierna por esa aptitud, talento o capacidad sin acogerse a textos escritos, a las leyes, en un concepto (predominio de los principios de la sabiduría sobre la ley) con el que polemizaría Aristóteles en La política arguyendo que las leyes son menos desapasionadas que los hombres y que los principios generales y la capacidad de esos hombres no son suficientes para gobernar con justicia. ${ }^{100}$

\subsection{Apuntes sobre la idea de mérito en la política de Aristóteles}

Si fuera posible simplificar el asunto hasta ese punto, podríamos convenir que la concepción aristotélica del mérito se halla articulada por dos notas: de un lado por su traducción eminentemente práctica, de otro, por su exposición del término medio o la virtud de la moderación ${ }^{101}$. En un plano político, la crítica a la falta de mérito de los pobres atiende a la perspectiva realista-descriptiva desde la que son observados. Aristóteles constata que a aquellos a quienes les falta lo necesario para vivir se dedican al trabajo. Prefieren ganancias a honores. ${ }^{102}$ Acerca de esta perspectiva,

99. STEVENSON, L.: Siete teorías sobre naturaleza humana, Madrid: Cátedra, 2001, p. 41. 100. BOBBIO, N.: El futuro de la democracia, México, FCE, 1986.

101. ARISTÓTELES: Política. IV 1290a.

102. ARISTÓTELES: Política. VI, 1318b

Thémata. Revista de Filosofía $\mathrm{N}^{\circ} 55$ (2017) pp.: 219-248. 
escribe Jaeger que con ella Aristóteles se distancia progresivamente de la fusión platónica de ética y conocimiento ${ }^{103}$. Para Castoriadis, Aristóteles rechaza con razón la equiparación alma-ciudad y la forma en que Platón abordaba la relación entre la política y virtud. Aunque para Aristóteles «la virtud cardinal es esencialmente política, la justicia" (Ética a Nicómaco, libro V), y aunque la mayor parte de las virtudes que él examina se refieren a las relaciones del individuo con los demás, no hay ni identidad ni analogía entre lo individual y lo colectivo» ${ }^{104}$. La crítica aristotélica desde una perspectiva sociológica atiende, sobre todo, a la psicología de ambos componentes de la polis y se relaciona con la idea de mérito, que es tratado, prácticamente sin juicios de valor. En la Política, al referirse a la libertad (eleuthería) como la base de la constitución democrática -aquella de la que abominaba Teognis- enuncia como el primero de sus signos o límites, el que en ella se gobierna y se deja de gobernar por turnos, y concretamente que el pueblo quiere tener derechos por el número y no por la riqueza o por los méritos. ${ }^{105}$ En la Política dice enfáticamente que la polis esta formada por dos mere: «los ricos y los pobres (plousioi y penetes)»" ${ }^{106}$. Tenemos otra vez la distinción fundamental entre hacendados y desheredados: euporoi y aporoi, para lo cual hay dos formas básicas de constitución: oligarquía y democracia. Técnicamente, la oligarquía sería, ese gobierno de los pocos (los oligoi), y la democracia el gobierno del dêmos, (donde el número predomina sobre el mérito). Dêmos término que unas veces significa el pueblo en su totalidad y otras, específicamente, las clases bajas, insistiendo en que el fundamento real de la diferencia entre democracia y oligarquía estriba en la pobreza y la riqueza. La asimetría conduce a dos desviaciones igualmente problemáticas: los pobres tratan de avanzar desde la igualdad política a la igualdad en la condición económica. Mientras que los ricos tratan de avanzar desde la desigualdad económica hacia la desigualdad política. Por este motivo, Aristóteles rechaza la desviación de la democracia porque actúa únicamente en dirección hacia los pobres y desvía a la aristocracia en una oligarquía que viene a ser una aristocracia sin méritos Aristóteles defendió la limitación de la gestión política según las diferencias económicas. Los trabajadores manuales, banausoi, sin tiempo libre, debían excluirse de la gestión política porque no podrían dedicarse a tales funciones. Se debe a Aristóteles además el intento explícito de legitimar no sólo esa exclusión, sino también, la del esclavo, para lo que recurre a las nociones anteriores: la cobertura de necesidades, su relación con la

103. JAEGER, W.: Aristóteles, México: F.C.E., 1997, p. 275 ss., y p. 483 ss.

104. CASTORIADIS, C.: El ascenso de la insignificancia, cit., p. 213.

105. ARISTÓTELES, Política, VI, 1317 a - 1318 a.

106. ARISTÓTELES, Política, VI. 3, 1.318a30-31.

Thémata. Revista de Filosofía N55 (2017) pp.: 219-248. 
virtud y las capacidades. El tiempo libre, la scholé, es la base de la verdadera libertad, «requisito para la ciudadanía más auténtica. De ésta, pues, quedan excluidos aquellos hombres que deben ocuparse en los trabajos urgentes de subsistencia, así como los que, por afanes económicos de lucro, se embrutecen en un trabajo demasiado absorbente y embrutecedor.» ${ }^{107}$

\section{A modo de conclusión}

El mérito es un concepto amplio ligado a los criterios de justicia. La idea de mérito no aparece originariamente en la génesis del liberalismo asociado al modelo burgués como talento o suma de ingenio y esfuerzo. Como idea que refiere los actos que, realizados por un sujeto, son dignos de premio o de castigo, es un concepto antiguo perteneciente al ámbito de la justicia, de la moral, de lo jurídico. Para Vernant, el nacimiento del concepto de mérito es inescindible del nacimiento del concepto de sujeto. Junto con el concepto de sujeto nace tanto el ideal de la excelencia (areté), según el cual cada persona deberá ser capaz de alcanzar el dominio de sí misma sobre la base de sus propias destrezas y capacidades, como las diferentes valoraciones de los actos, en sus formas estática y dinámica, (axía y axiosis). En todo modelo social subyace una escala de méritos y valores que determina reparto de beneficios, cargos posiciones, derechos y privilegios pero también un régimen de sanciones, un elenco de obligaciones, un sistema de exclusión. La complejidad de la relación entre mérito de la acción y del sujeto en el ámbito de la justicia distributiva, en la más general necesidad de distinguir entre la acción meritoria y el sujeto meritorio, obligan a retener también una serie de matizaciones: (1) El carácter contingente del mérito no permite presuponer la coincidencia de lo que hoy entendemos por mérito en el contexto de la Antigüedad griega donde apareció la noción de demokratía; (2) A lo largo de la historia, apenas hay un periodo en el que no se haya teorizado la mejor aptitud de un grupo para ostentar poder por encima de los que no reúnen tales requisitos. Es este el fenómeno que Weber estudió como "teodicea del propio privilegio» en su análisis de la dominación y la legitimidad ${ }^{108}$.

La confusa noción de meritocracia, muchas veces poliédrica en sus sentidos, usos y significados aconseja no partir de nuestras propias ideas -las de nuestra época- acerca del sentido de lo meritorio. El mayor grado de similitud con nuestra noción de mérito lo encontramos en el enfoque que Musti hacía de uno de los pasajes más conocidos del discurso de Peri-

107. GARCÍA GUAL, C.: «La Grecia Antigua», en Historia de la teoría política, (I), cit., p. 156. 108. WEBER, M.: Economía y sociedad, cit., p. 705.

Thémata. Revista de Filosofía $\mathrm{N}^{\circ} 55$ (2017) pp.: 219-248. 
cles según el testimonio de Tucícides: «Según la valoración (axíosis) según el crédito que consiga en una actividad, no se le prefiere por la riqueza más que por sus méritos (excelencia, virtud, aretê), ni se ve obstaculizado por su estatus social (axioma), si es capaz de prestar un buen servicio a la ciudad». Como nos hemos ocupado de recordar, el significado de mérito siempre es próximo al de valoración. La diferencia entre axíosis y axio$m a$ estriba en que el primer término indica valoración, mientras que el segundo indica un estado. En este sentido, la axiosis presenta una perspectiva democrática del concepto de mérito desde la meritocracia en su sentido etimológico, como proceso en curso de formación: ser acreedor de la recompensa que cada cual conquista. En efecto, según Tucídides, Pericles intentó que la democracia aspirara a ser un modelo que favoreciera el desarrollo de las aptitudes personales y donde se recompensara dinámicamente a los mejores con cargos y responsabilidades. Pero evidentemente la valoración de la inteligencia y del esfuerzo en términos meritocráticos es completamente diferente en la Atenas del siglo IV antes de Cristo que en la Europa de la Ilustración; al mismo tiempo la disimilitud del contenido de lo que llamamos "inteligencia» a lo largo de la historia impide la aplicación de nociones contemporáneas. El problema no debe plantearse en esos términos. Únicamente una visión amplia de la idea de mérito, merecimiento, permitirá encontrar el germen de la noción meritocrática en unos parámetros temporales y vitales muy diferentes.

La riqueza de los poemas de Homero ha autorizado a ver en ellos desde la defensa del esfuerzo en el episodio de los latófagos donde los perezosos son ahuyentados y llevados a galeras ${ }^{109}$, a la nobleza, la audacia o la fuerza. El dato principal sigue siendo la íntima conexión del mérito con el principio agonal y el nexo moral que une acción y recompensa. Retengamos esto: el término areté no connota solo excelencia sino también capacidad para sobresalir. Mediante su influjo el agathós (bueno) se convierte en aristós (el mejor), el héroe homérico no es realmente feliz si no se siente, si no se afirma como el primero. Hesíodo supone la valoración del esfuerzo ligado al sacrifico y al trabajo y lo incluimos como segundo modelo de mérito en un sentido dinámico. Pero al margen de la línea que inaugura Trabajos y días (el esfuerzo digno de recompensa) podemos decir sin temor a ser reductivos que la época arcaica es el tiempo de la areté heroica.

El mérito eugenésico mira al pasado, al tiempo heroico, la sangre en las venas de los descendientes. Si el contenido del mérito en la época homérica significaba el triunfo de la areté heroica por la que se recompensa los hechos realizados (la acción que merece ser contada), y el héroe homérico es agathós por su perseguir objetivos con valor y audacia per-

109. HOMERO: Odisea, IX, 229.

Thémata. Revista de Filosofía N55 (2017) pp.: 219-248. 
sonal, la época arcaica, básicamente aristocrática, insiste en el mérito del sujeto como depositario de una mejor aptitud para el kratos derivada de su estirpe. El mérito eugenésico se refiere al nacimiento noble, a la eugeneia, a los eupátridas. Su representación paradigmática es la lírica de Píndaro o Teognis de Mégara. Como ponían de relieve Ste Croix o Gschnitzer ${ }^{110}$, la política, el gobierno y la administración de las comunidades en este tiempo es competencia de propietarios acomodados cuya habilidad inicial no significa adentrarse en el mundo comercial o hacer "carrera» en él, ${ }^{111}$ sino una riqueza ya poseída. Para Platón el pobre no es enteramente dueño de sí, (penés on kai heautou mé kratón) ${ }^{112}$, mientras que para Aristóteles la labor del trabajador manual es incompatible con la virtud presentada en estrecha unión con la politeia. Ya que las magistraturas son funciones honoríficas no remuneradas, quien se dedique un año a su cargo no puede trabajar de forma permanente en su hacienda o taller, tampoco puede emprender viajes comerciales. Sólo los acomodados pueden desempeñar magistraturas. La Grecia antigua como focus histórico social también legitimó el dominio de un grupo sobre otro en detrimento de una raza, un sexo, o una cultura sobre la base de la mejor capacidad en forma estática (axía), natural u orgánica. El mérito del hombre frente a la mujer sigue esgrimiéndose desde Homero al Platón del Menón. Nos hemos detenido anecdóticamente en su modelo y en algunas alusiones al mérito en la inabarcable obra de Aristóteles. La democracia significó una revisión de las bases meritorias al cuestionar el origen heterónomo de normas y valores, y ser, por decirlo como Castoriadis, el primer intento de conciliación de la autonomía colectiva e individual alrededor de la política, en un momento en el que la institución de la sociedad abandona parte de sus presupuestos, si no sagrados, sí tradicionales, y cuando la cuestión de la justicia es la cuestión de la política ${ }^{113}$.

110. GSCHNITZER, F.: Historia social de Grecia, cit., p.56 y ss.

111. STE CROIX, G.: op., cit. p. 456

112. PLATÓN: Carta VII, 351a

113. CASTORIADIS, C.: El ascenso de la insignificancia, cit., p. 231.

Thémata. Revista de Filosofía $\mathrm{N}^{\circ} 55$ (2017) pp.: 219-248. 